\title{
ライフラインの途絶に備えた対策がもたらす 地域のレジリエンス向上効果の評価手法の提案
}

地域レベルのエネルギーシステムによるレジリエンス向上効果の貨幣価值評価

\section{PROPOSAL OF AN EVALUATION METHOD FOR RESILIENCE IMPROVEMENTS CONSIDERING LIFELINE SUPPLY STOPPAGES}

Evaluation of monetary value for resilience improvements by introducing a community energy system

\author{
大束開智*，伊香賀 俊治**，村上周三***，工月良太 太 $^{* * *}$, 川除隆広***** \\ Kaichi OTSUKA, Toshiharu IKAGA, Shuzo MURAKAMI, \\ Ryota KUZUKI and Takahiro KAWAYOKE
}

\begin{abstract}
A community energy system is expected to contribute to improving the resilience and regional vitalization not only carbon emission reduction. Prior studies did not accrued non-energy benefits by the risk aversion with respect to temporal changes in business and daily life activities associated with lifeline utilities such as electricity, water, and gas. This paper focuses on the following issues;

1. To propose estimation method for resilience improvements based on Resiliency Factor and a recovery curve for business activity according to the lifeline stoppage time.

2. To derive a basic unit of loss due to electric power failure according to stoppage time, derive the estimation model of a basic unit that considered housing form and address of residence, proposed an evaluation method for resilience in the housing sector in monetary terms.

3. To perform case studies of evaluation of monetary value for resilience improvements by introducing a community energy network.
\end{abstract}

Keywords: Decentralized Energy, Co-benefits, Business Continuity District, Resiliency Factor,

分散型エネルギー，コベネフィット，業務継続地区，レジリエンシーファクター

1. はじめに

東日本大震災でのエネルギー供給の途絶やその後の電力需給逼迫 の経験を受け, 我が国では人口や都市機能が集積した地区において, 災害時にライフラインの供給が確保される業務継続地区（BCD： Business Continuity District) 1)の構築が打出されている。この事 から, 低炭素化だけでなくレジリエンス（本研究ではライフライン 途絶時の業務活動や生活機能の自立性の意味で用いる）への貢献が 期待される地域レベルでのエネルギーシステムの導入促進が求めら れている2)。これは，コージェネレーションシステムや地域の建物 間の電力・熱を相互融通するネットワーク等で形成し，地域レベル でエネルギーを効率的に利用するシステムである。電力や都市ガス が途絶した災害時には分散型電源からの電力・熱供給により業務・ 生活継続への貢献が期待される。しかしながら, 建物単体の低炭素 化対策と比較して大規模な対策であるため，初期投資の高さや多様 なステークホルダーの存在等が導入を妨げる課題とされている。課
題解決に向けて文献 3)では, 低炭素化対策により享受される光熱水 費等の直接的便益（EB：Energy Benefit）の他に，対策によって創 出される間接的便益 (NEB : Non-energy Benefits)の定量的な把握 およびステークホルダー間での認識の共有が必要であると述べてい る。既往研究 4),5)において, エネルギーの面的利用がもたらす多面的 な NEB の明確化やステークホルダーを考慮した費用対便益による 評価を行い，地域レベルでの自立分散型のエネルギーシステムの構 築による便益が費用を上回ることを示している。工月らが提案した NEB の貨幣価值換算要綱には「BLCP（業務・生活継続計画）への 貢献一エネルギー供給停止時の損失回避効果」というリスク回避に よる便益が提案されている。これは文献值 ${ }^{6}$ )の停電時の被害額原単 位に当該区に導入を想定した分散型電源容量を掛け合わせて推計す る式注 1)であり, 電力以外の都市ガスや水道も含む複合的なライフラ イン途絶状況や各ライフラインの復旧に伴う業務活動や生活機能の 時間変化を考慮した評価はされていない。地域レベルでのライフラ

\footnotetext{
* 慶應義塾大学大学院理工学研究科 大学院生

** 慶應義塾大学理工学部 教授・博士(工学)

*** (一財) 建築環境・省エネルギー機構 理事長・工博

**** 東京ガス株)エネルギー企画部 博士(工学)

Grad. Student, Graduate School of Science and Technology, Keio Univ.

Prof. Faculty of Science and Technology, Keio Univ., Dr. Eng.

President, Institute for Building Environment and Energy Conservation, Dr. Eng.

Energy Strategy Planning Dept., Tokyo Gas Co., Ltd., Dr. Eng.

(株)日建設計総合研究所 上席研究員・博士 (工学)

Senior Researcher, Nikken Sekkei Research Institute, Dr. Eng.
} 
インの途絶に備えた対策による非常時の業務活動や生活活動の損失 が回避されることを便益としてより適切に定量化することが，導入 促進のうえで有効であると考えられる。

米国では専門家アンケートによりライフライン（電力・水道・ガ ス)の途絶に対する業務活動の影響度合い (RF:Resiliency Factor) を ACT-13 やその更新版の ACT-257) という指標で提案している。我 が国では, 梶谷ら 8)が業務継続に関する経済被害の推計を目的とし て, RF 「ライフライン途絶抵抗係数」と定義し, 愛知県と静岡県 の製造業・非製造業を対象としたアンケート調査により，0（生産停 止）から 1 (平常時と同じ生産レベル) の間の值で定量化した。ま た，梶谷らはライフラインの復旧の時間変化に着目し，東日本大震 災の被害データを用いて, 製造業・非製造業の生産能力の回復曲線 を導出している。これにより, 途絶直後だけでなく復旧期間を考慮 した業務部門の業務活動を推計する手法が提案されている。しかし ながら, 梶谷らが推計した $\mathrm{RF}^{8}{ }^{8}$ は, 東日本大震災以前のアンケート 調査に基づいており, 震災後の業務継続に対寸る国民の意識の変化 が反映されたものではない。一方, 生産能力の回復曲線は, 東日本 大震災における津波や原子力発電所の影響を考慮しており, 災害発 生からある日数が経過しても生産能力が 1 (平常時と同じ生産レベ ル）に戻らないモデルとなっている。このことから, 既往研究では 今後のライフラインの途絶に備えた対策のレジリエンス評価に必要 な知見としては不十分であると考えられる。

そこで，本研究では下記の 3 点の評価を行う。

（1）非製造業の従事者を対象とした Web アンケート調査から業務 部門における RF 及び業務活動の回復曲線を導出する。

（2）居住者を対象とした Web アンケート調査から復旧の時間変化 を考慮した住宅部門における停電に対する損失額の原単位及び 原単位の推計モデルを導出する。

（3）業務・住宅複合地区を対象にケーススタディを行い，エネルギ ーシステムによる地域のレジリエンスの向上効果を評価する。

上記のような地域レベルのライフラインの途絶に備えた対策がも たらすレジリエンス向上効果の評価手法を提案することで, 事業推 進の一助になることを目指す。

\section{2. 業務部門のレジリエンスの評価}

\section{2-1 ライフラインの途絶に対する RF の把握}

業務部門における $\mathrm{RF}$ を推計するために, 非製造業の従事者を対 象にアンケート調查を実施した。表 1 にアンケート調査の概要を示 す。本研究の RF は既往研究 7),8)を参考に, 0 (業務活動の完全停止) から 1 （通常通りの業務ができる）の值で指標化する。本論文では 表 2 のように電力を $\mathrm{E}$, 水を $\mathrm{W}$, 都市ガスを $\mathrm{G}$ とし, 途絶の有無を ○, $\times$ で示す。また, RF 推計式の説明のために途絶状況を $\{i \mid i=0,1 \ldots 6\}$ と示す。本調查ではライフラインが全て途絶した場合 $(i=0)$ といずれか一つが途絶した場合 $(i=1,2,3)$ において勤務先の業 務活動への影響について質問した。表 3 に一例として電力のみ途絶 した場合の質問を示す。回答者が想定する途絶時間は, 既往研究 9) を参考に “(1)数時間〜1 日程度の途絶”, “(2) 1 日を超えた数日程度 の途絶” と設定し, 本研究では震災等の長期的な途絶を想定した評 価を行うため, (2)の回答を用いる。図 1 に回答者の構成比を示す。 性別は男性が 9 割以上を占めており, 年代は 50 代が 5 割を占めた。
表 1 Web アンケート調査概要

\begin{tabular}{|c|c|}
\hline 目的 & ライフラインの途絶に対する業務活動への影響把握のため \\
\hline 期間 & 2015 年 10 月 $27 \sim 29$ 日 \\
\hline 回收数 & 依頼: $1,487 \mathrm{~s}$ 回収: $1,208 \mathrm{~s}$ 有効数: $1,103 \mathrm{~s}(74.2 \%)^{\text {羊 } 2)}$ \\
\hline 対象者 & $\begin{array}{l}\text { 非製造業の従事者かつ } \\
\text { 事務系, 営業系, 技術・開発系職種の者（全国) }\end{array}$ \\
\hline $\begin{array}{c}\text { 質問項目 } \\
(19 \text { 問) }\end{array}$ & $\begin{array}{l}\text { （1）勤務先の業務継続計画について } \\
\text { （2）各ライフラインの途絶に対する業務活動について } \\
\text { （3）勤務先のオフィスについて }\end{array}$ \\
\hline
\end{tabular}

表 2 ライフライン途絶状況の設定

\begin{tabular}{|l|l|}
\hline ライフラインの途絶状況 & $i$ \\
\hline 全て途絶 $(\mathrm{E} \times \mathrm{W} \times \mathrm{G} \times)$ & 0 \\
\hline 電力のみ途絶 $(\mathrm{E} \times \mathrm{WOGO})$ & 1 \\
\hline 水のみ途絶 $(\mathrm{EOW} \times \mathrm{GO})$ & 2 \\
\hline 都市ガスのみ途絶 $(\mathrm{EOWOG} \times)$ & 3 \\
\hline 電力のみ復旧 $(\mathrm{EOW} \times \mathrm{G} \times)$ & 4 \\
\hline 水のみ復旧 $(\mathrm{E} \times \mathrm{WOG} \times)$ & 5 \\
\hline 都市ガスのみ復旧 $(\mathrm{E} \times \mathrm{W} \times \mathrm{GO})$ & 6 \\
\hline
\end{tabular}

表 3 質問例（電カのみ途絶した場合）

\begin{tabular}{|c|c|}
\hline 質問文 & 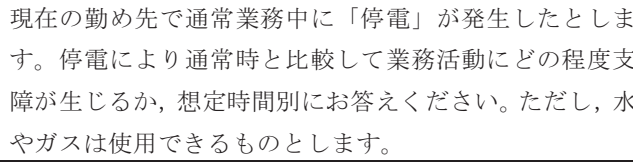 \\
\hline 途絶時間 & $\begin{array}{l}\text { (1) 数時間〜 } 1 \text { 日程度の途絶（例：風水害，人為的事故） } \\
\text { (2) } 1 \text { 日を超えた数日程度の途絶（例：震災等) }\end{array}$ \\
\hline
\end{tabular}

[1] 業務活動の完全停止 (0\%)

[2] 大きな支障をきたし, 継続できる業務が少ない $(25 \%)$

選択肢 [3] 通常時の半分は業務が継続できる $(50 \%)$

[4] あまり支障はなく，継続できる業務が多い（75\%)

[5]通常通りの業務ができる (100\%)

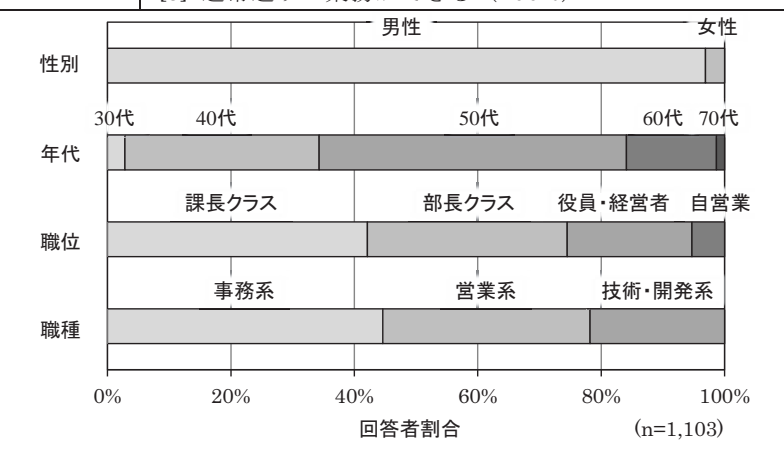

図 1 回答者の構成比

ライフラインが全て途絶した場合 $(i=0)$ といずれか一つが途絶した 場合 $(i=1,2,3) の R F_{i}$ は, 表 3 のよう質問から業務活動の回答結果を 業種別に平均化することで推計する。式(1)に推計式を示す。

$$
R F_{i}=\frac{1}{n} \sum_{j=1}^{n} x_{j} \quad(i=0,1,2,3)
$$

$(n:$ 各業種の回答の総数 $x$ : 回答結果 $(0.00,0.25,0.50,0.75,1.00))$

図 2 にいずれか一つが途絶した場合 $(i=1,2,3) の R F_{i}$ の推計結果を業 種別に示す。どの業種も電力の夕途絶の $\mathrm{RF}$ が水や都市ガスの途絶 の $\mathrm{RF}$ よりも小さいことから，電力が $\mathrm{RF}$ に最も大きく影響を及ぼ すことが分かった。また, 業種間ではサービス業や宿泊業などの業 種の $\mathrm{RF}$ が低い傾向が得られた。これにより，業種によって RF が 異なる傾向を示すことが確認できた。 


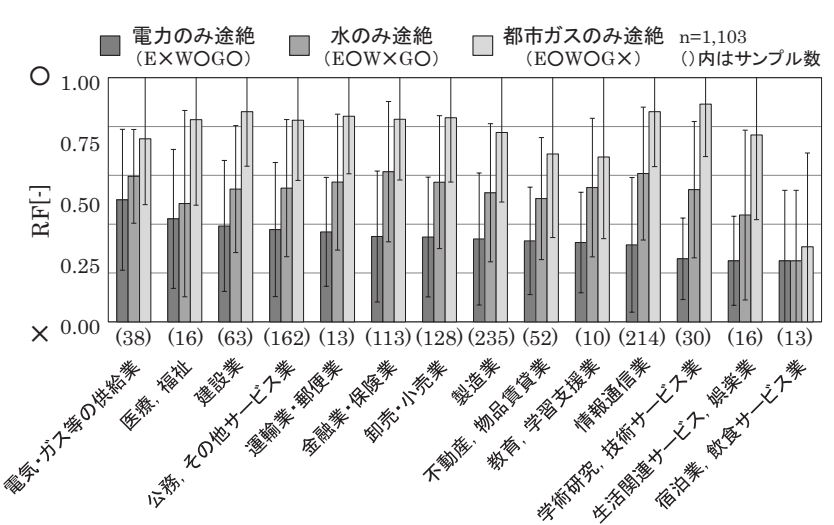

図 2 アンケート調査による $\mathrm{RF}_{\mathrm{i}}(\mathrm{i}=1,2,3)$ の推計結果

次に, アンケートから推計した $R F_{i}(i=0 \sim 3)$ から残りの

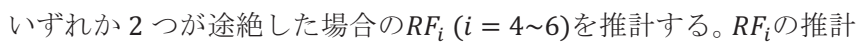
には, RF の定義が熱交換器における総括熱伝達係数の考え方と同 様であると考え, 推計に適用寸る。熱交換において 3 層からなる伝 熱量と温度差の関係式は式(2)となる。

$$
\Delta t_{1}+\Delta t_{2}+\Delta t_{3}=\left(\frac{d_{1}}{\lambda_{1}}+\frac{d_{2}}{\lambda_{2}}+\frac{d_{3}}{\lambda_{3}}\right) \frac{Q}{S}
$$

$\left(\begin{array}{l}\Delta t: \text { 温度差 }\left[{ }^{\circ} \mathrm{C}\right] \quad \lambda: \text { 伝熱係数 }[\mathrm{W} / \mathrm{m} \cdot K] \quad d: \text { 伝熱距離 }[\mathrm{m}] \\ Q: \text { 伝熱量 }[\mathrm{W}] \quad S: \text { 面積 }\left[\mathrm{m}^{2}\right]\end{array}\right)$ また, 3 層全体の伝達量と温度差の関係式は式(3)となる。そして式 (2)と式(3)の関係が等しくなることから式(4)の関係式が成り立つ。

$$
\begin{gathered}
\Delta t=\frac{d}{\lambda} \cdot \frac{Q}{S} \\
\frac{d}{\lambda}=\frac{d_{1}}{\lambda_{1}}+\frac{d_{2}}{\lambda_{2}}+\frac{d_{3}}{\lambda_{3}}
\end{gathered}
$$

式(4)の伝熱係数入を途絶に対する $R F_{i}$, 伝熱距離 $d$ を業務活動への 影響の違いを示す重み係数に置き換えると式(5)となる。

$$
\frac{d}{R F}=\frac{d_{\mathrm{E}}}{R F_{\mathrm{E} \times \mathrm{WoGo}}}+\frac{d_{\mathrm{W}}}{R F_{\mathrm{EoW} \times \mathrm{Go}}}+\frac{d_{\mathrm{G}}}{R F_{\mathrm{EoWoG} \times}}
$$

重み係数は, 既往研究 8 )で推計された業種別の $R F_{i}$ における各ライ フラインの相互関係を参考に, $\frac{d_{E}}{d}=0.8 \frac{d_{W}}{d}=0.5 \frac{d_{G}}{d}=0.3$ とした。 以上からいずれか $2 つ か ゙$ 途絶した場合の $R F_{i}(i=4 \sim 6)$ は, 式(6) (8) から推計される。表 4 に全 13 業種の各途絶状況に対する $R F_{i}$ の推計 結果を示す。

$$
\begin{aligned}
& R F_{\mathrm{EoW} \times \mathrm{G} \times}=\frac{1}{\frac{0.8}{1}+\frac{0.5}{R F_{\mathrm{EoW} \times \mathrm{Go}}}+\frac{0.3}{R F_{\mathrm{EoWoG} \times}}} \\
& R F_{\mathrm{E} \times \mathrm{WoG} \times}=\frac{1}{\frac{0.8}{R F_{\mathrm{E} \times \mathrm{WoGo}}}+\frac{0.5}{1}+\frac{0.3}{R F_{\mathrm{EoWoG} \times}}} \\
& R F_{\mathrm{E} \times \mathrm{W} \times \mathrm{Go}}=\frac{1}{\frac{0.8}{R F_{\mathrm{E} \times \mathrm{WoGo}}}+\frac{0.5}{R F_{\mathrm{EoW} \times \mathrm{Go}}}+\frac{0.3}{1}}
\end{aligned}
$$

\section{2-2 対策によるレジリエンス向上効果の評価方法}

2-1 で導出した RF を用いて, ライフラインの途絶に備えた対策 によるレジリエンス向上効果の評価方法を提案する。本研究では, 災害直後だけでなく, 各ライフラインの復旧期間を考慮した業務活 動の回復曲線を導出することで, 業務活動の時間変化を踏まえた評 価を行う。回復曲線の導出には, 途絶状況別のRF $i$ をプロットし, 式 (9)に示すロジスティック曲線で近似することで導出する。図 3 に回 復曲線の導出方法のイメージを示す。ロジスティック曲線で近似す る理由として, 文献 10)では業務活動が $\mathrm{S}$ 字型に回復すると考えられ ることから，本研究ではロジスティック曲線を適用した。

$$
F(t)=\frac{1}{1+\exp (A t+B)}
$$

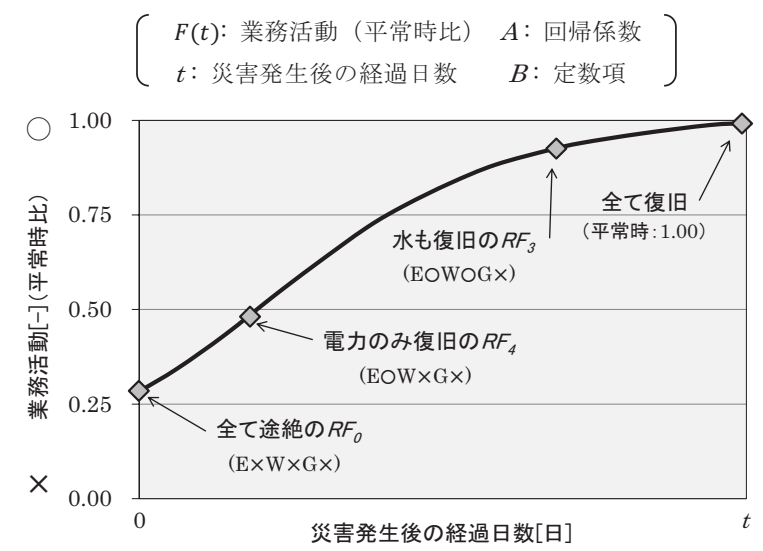

\begin{tabular}{|c|c|c|c|c|c|c|c|c|c|}
\hline & $\mathrm{E} \times \mathrm{W} \times \mathrm{G} \times$ & $\mathrm{E} \times \mathrm{W} \circ \mathrm{G} \circ$ & $\mathrm{E} \circ \mathrm{W} \times \mathrm{G} \circ$ & $\mathrm{E} \circ \mathrm{W} \circ \mathrm{G} \times$ & $\mathrm{E} \circ \mathrm{W} \times \mathrm{G} \times$ & $\mathrm{E} \times \mathrm{W} \circ \mathrm{G} \times$ & $\mathrm{E} \times \mathrm{W} \times \mathrm{G}_{\circ}$ & 平均值 & サンプル值 \\
\hline 電気・ガス・熱供給・水道業 & 0.3462 & 0.5000 & 0.5962 & 0.7500 & 0.4905 & 0.4000 & 0.3651 & 0.5256 & 13 \\
\hline 医療, 福祉 & 0.2813 & 0.4219 & 0.4844 & 0.8281 & 0.4557 & 0.3625 & 0.3097 & 0.5003 & 16 \\
\hline 建設業 & 0.3016 & 0.3929 & 0.5437 & 0.8611 & 0.4835 & 0.3467 & 0.3071 & 0.4987 & 63 \\
\hline 公務, その他サービス業 & 0.2546 & 0.3781 & 0.5478 & 0.8256 & 0.4817 & 0.3357 & 0.3004 & 0.4771 & 162 \\
\hline 運輸業, 郵便業 & 0.2632 & 0.3684 & 0.5724 & 0.8421 & 0.4927 & 0.3303 & 0.2990 & 0.4839 & 38 \\
\hline 金融業, 保険業 & 0.2655 & 0.3496 & 0.6150 & 0.8296 & 0.5064 & 0.3174 & 0.2940 & 0.4844 & 113 \\
\hline 卸売・小売業 & 0.2363 & 0.3477 & 0.5723 & 0.8359 & 0.4920 & 0.3165 & 0.2878 & 0.4692 & 128 \\
\hline 製造業 & 0.2330 & 0.3394 & 0.5287 & 0.7755 & 0.4689 & 0.3082 & 0.2775 & 0.4400 & 235 \\
\hline 不動産業, 物品賃貸業 & 0.2933 & 0.3317 & 0.5048 & 0.6875 & 0.4491 & 0.2987 & 0.2915 & 0.4453 & 52 \\
\hline 教育, 学習支援業 & 0.2250 & 0.3250 & 0.5500 & 0.6750 & 0.4644 & 0.2936 & 0.2724 & 0.4405 & 10 \\
\hline 情報通信業 & 0.2220 & 0.3154 & 0.6075 & 0.8610 & 0.5072 & 0.2954 & 0.2733 & 0.4703 & 214 \\
\hline 学術研究, 専門・技術サービス業 & 0.1500 & 0.2583 & 0.5417 & 0.8917 & 0.4855 & 0.2542 & 0.2315 & 0.4121 & 30 \\
\hline 生活関連サービス業, 娛楽業 & 0.1406 & 0.2500 & 0.4375 & 0.7656 & 0.4283 & 0.2444 & 0.2154 & 0.3810 & 16 \\
\hline 宿泊業, 飲食サービス業 & 0.1154 & 0.2500 & 0.2500 & 0.3077 & 0.2439 & 0.2139 & 0.1818 & 0.2293 & 13 \\
\hline 全体 & 0.2377 & 0.3449 & 0.5251 & 0.7669 & 0.4666 & 0.3114 & 0.2800 & 0.4470 & 1103 \\
\hline
\end{tabular}

図 3 回復曲線の導出方法のイメージ

次に対策によって向上する $\mathrm{RF}$ 'を推計し, 同様に回復曲線を導出 する。地区によって導入される対策が異なることから，RF'は対策 の供給能力に従って推計する必要がある。本研究では通常の燃料備 蓄で賄える範囲を超えた長期的な業務や生活継続に着目しており， 式(10) (12)のように対策による各供給力を容量から定義する。

表 4 業種別の RF 推計結果（黒枠は合成値） 


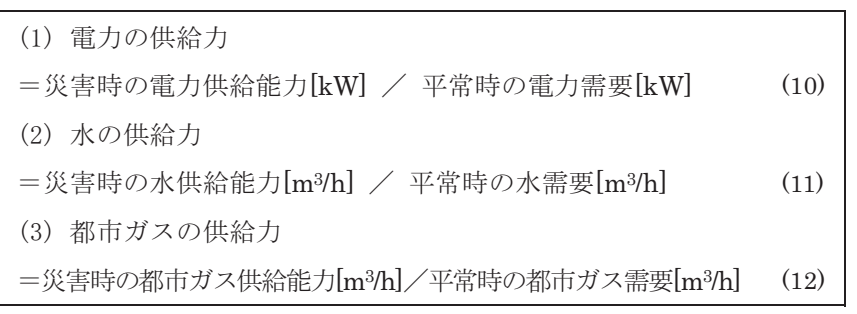

また， $2-1$ とは別に表 4 の推計した $R F_{i}$ から各ライフラインの復旧 に対する重み係数を表 5 のように定義する。

\section{表 5 各ライフラインの復旧に対する重み係数}

\begin{tabular}{|c|c|}
\hline 途絶状況 $i$ & 復旧に対する重み係数 $\alpha_{i}$ \\
\hline $4(\mathrm{E} \circ \mathrm{W} \times \mathrm{G} \times)$ & $\alpha_{4}=R F_{4} /\left(R F_{4}+R F_{5}+R F_{6}\right)$ \\
\hline $5(\mathrm{E} \times \mathrm{W} \circ \mathrm{G} \times)$ & $\alpha_{5}=R F_{5} /\left(R F_{4}+R F_{5}+R F_{6}\right)$ \\
\hline $6(\mathrm{E} \times \mathrm{W} \times \mathrm{G} \circ)$ & $\alpha_{6}=R F_{6} /\left(R F_{4}+R F_{5}+R F_{6}\right)$ \\
\hline
\end{tabular}

上記の供給力と重み係数 $\alpha_{i}$ から対策によって向上する $R F^{\prime}{ }_{i}$ の増 加率 $\beta_{i}$ を式(13)のように定義する。

$$
\beta_{i}=\alpha_{4} \times(\text { 電力の供給力 })+\alpha_{5} \times(\text { 水の供給力 })+\alpha_{6} \times(\text { 都市ガスの供給力 })
$$

平常時との差と増加率 $\beta_{i}$ を掛け, $R F_{i}$ に足し合わせた対策後の $R F^{\prime}{ }_{i}$ を式(14)のように推計する。

$$
R F^{\prime}{ }_{i}=R F_{i}+\left(1-R F_{i}\right) \times \beta_{i} \quad(i=0,3,4)
$$

式(14)から対策後の $R F^{\prime}{ }_{i}$ を推計することで, 図 4 のように対策後 ケースの回復曲線を導出することができる。

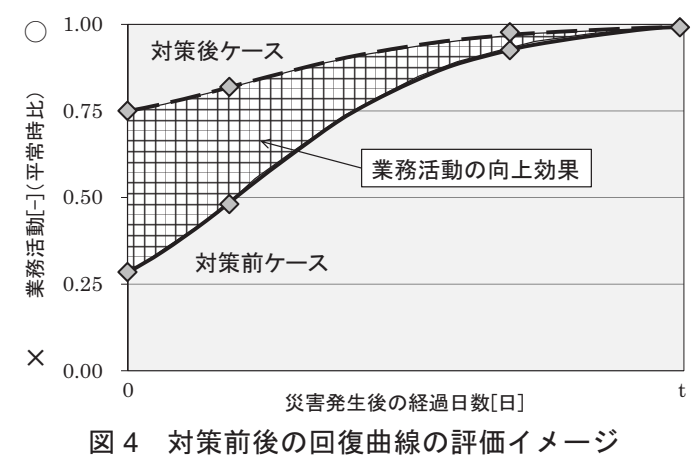

図 4 の業務活動の向上効果の面積（単位は日）に，業務活動の原 単位を掛けることで, ライフラインの途絶に備えた対策によるレジ リエンス向上効果を貨幣価值換算として評価する。業務活動の向上 分の面積に対する推計式を式(15)に, レジリエンス向上効果の推計 式を式(16)に示す。一回の災害に対するレジリエンスの向上効果を 1 年間あたりの金額で評価するために, 想定する災害の発生確率を 掛け合わせ，期待值として定義する。

$$
S=\int_{0}^{t_{4}}\left\{F^{\prime}(t)-F(t)\right\} d t
$$

$\left(\begin{array}{l}S: \text { 業務活動の向上分の面積 } t_{4}: \text { 全て復旧寸る日数 } \\ F(t): \text { 対策前の業務活動, } F^{\prime}(t): \text { 対策後の業務活動 }\end{array}\right)$

業務部門のレジリエンス向上効果[円/年]

$=\underset{\text { 向上業務活動の }}{\text { 面積 }}[$ 日 $] \times$ 業務活動の原単位 $\left[\mathrm{m} / \mathrm{m}^{2} \cdot\right.$ 日]

$\times$ 建物用途別 $\sigma\left[\mathrm{m}^{2}\right] \times$ 災害発生確率 [-/ / 年 $]$

(16)
式(16)の業務活動の原単位は, 資源エネルギー庁のエネルギー消 費量統計調查結果 11) と国土交通省の建築物着工統計 ${ }^{12}$ ) ように業種別の延床面積あたりの業務活動原単位注 3) を作成した。 ケーススタディでの建物用途が事務所の場合は，東京都のオフィス ビルにおける主要な業種の占有面積割合で加重平均した数値

\begin{tabular}{|c|c|c|c|}
\hline \multicolumn{2}{|r|}{ 区分 } & $\begin{array}{c}\mathrm{H} 17 \sim \mathrm{H} 26 \\
\text { 床面積比率 } \\
{[\%]} \\
{[\%]}\end{array}$ & $\begin{array}{c}\text { 業務活動 } \\
\text { 原単位 } \\
\text { [円/m² } \text {. 日] }\end{array}$ \\
\hline \multirow{4}{*}{ (1) } & 情報通信業 & 8.54 & 6,879 \\
\hline & 金融業, 保険業 & 6.24 & 4,995 \\
\hline & 不動産業, 物品賃貸業 & 85.22 & 912 \\
\hline & <事務所 > 上記合計 & 100.00 & 1,677 \\
\hline (2) & \multicolumn{2}{|l|}{ 運輸業, 郵便業 } & 791 \\
\hline (3) & \multicolumn{2}{|l|}{ 卸売業, 小売業 } & 3,297 \\
\hline (4) & \multicolumn{2}{|l|}{ 学術研究, 専門・技術サービス業 } & 2,417 \\
\hline (5) & \multicolumn{2}{|l|}{ 宿泊業, 飲食サービス業 } & 528 \\
\hline (6) & \multicolumn{2}{|l|}{ 生活関連サービス業, 娛楽業 } & 1,037 \\
\hline (7) & \multicolumn{2}{|l|}{ 教育, 学習支援業 } & 152 \\
\hline 8 & \multicolumn{2}{|l|}{ 医療業 } & 915 \\
\hline (9) & \multicolumn{2}{|l|}{ 社会保険・社会福祉・ 介護事業 } & 337 \\
\hline (10) & \multicolumn{2}{|l|}{ サービス業（他に分類されないもの） } & 615 \\
\hline
\end{tabular}
(1,677 円 $/ \mathrm{m}^{2}$ ・日) を用いる。

表 6 業種別の延床面積あたりの業務活動原単位

\section{3. 住宅部門のレジリエンスの評価}

\section{3-1 停電に対する延床面積別の損失額原単位の導出}

既往研究 ${ }^{4), 99}$ は, 住宅部門のレジリエンス向上効果を暫定的に停 電に対する損失額原単位の文献值で評価しているが，途絶時間を考 慮した評価はされていない。そこで, 本研究では居住者への Web ア ンケート調査から途絶時間を考慮したレジリエンス向上効果の評価 に用いる損失額原単位を導出する。表 7 に調査概要を示す。表 8 の ように居住者には突発的な停電を想定し, 途絶時間別に損失額を質 問した。ケーススタディにおいて, 建物用途別の延床面積を地区情 報として利用するため, 損失額に各回答者の住まいの延床面積を除 した延床面積別の損失額原単位 $\left[\mathrm{m} / \mathrm{m}^{2}\right]$ を住宅部門のレジリエンス 評価に用いる原単位として定義する。本調査では水や都市ガスの途 絶について評価に含まれておらず，追加調査により水や都市ガスに 関する原単位を把握する必要があり，今後の課題である。

図 5 にアンケート回答者の個人属性, 図 6 に住宅属性の集計結果 を示す。各質問で無回答やその他と回答した者はサンプルから除外 した。年代にはサンプルにやや偏りがあるが, どの項目もある程度

\begin{tabular}{|c|c|}
\hline 目的 & 住宅における停電・節電に対する意識の把握のため \\
\hline 期間 & 2013 年 3 月 $1 \sim 4$ 日 \\
\hline 回収数 & 依頼数: $2,203 \mathrm{~s}$ 回収: $1,657 \mathrm{~s}$ 有効サンプル: $920 \mathrm{~s}$ \\
\hline 対象者 & 戸建住宅，集合住宅に在住している者（全国） \\
\hline $\begin{array}{c}\text { 質問項目 } \\
(36 \text { 問 })\end{array}$ & $\begin{array}{l}\text { （1）停電/節電時の損害額や支払意志額について } \\
\text { (2) 回答者の性別や年代, 居住地等の個人属性について } \\
\text { （3）築年数や構造, 延床面積等の住宅属性について }\end{array}$ \\
\hline
\end{tabular}
均等に回収できた。

\section{表 7 アンケートの調査概要}




\section{表 8 質問例（突発的な停電が発生した場合）}

\begin{tabular}{|c|c|c|}
\hline 質問文 & \multicolumn{2}{|c|}{$\begin{array}{l}\text { 現在のお住まいにおける日常生活中に「想定できない突発的な停電」が合 } \\
\text { った場合, どの程度の損害額となりますか。以下に示す停電時間ごとにお } \\
\text { 答えください。なお損害額は, 電子機器の故障や冷蔵庫内の食料品の廃革, } \\
\text { 防苂グッズの使用など,「「直接的な損害額」を意味します。 }\end{array}$} \\
\hline 停電時間 & \multicolumn{2}{|c|}{10 分, 1 時間, 3 時間, 6 時間, 12 時間, 24 時間, 48 時間 } \\
\hline \multirow{5}{*}{ 選択肢 } & (1) 損害なし & (6) 4,000 円以上 5,000 円未満 \\
\hline & (2) 1,000 円未満 & (7) 5,000 円以上 10,000 円未満 \\
\hline & (3) 1,000 円以上 2,000 円未満 & (8) 10,000 円以上 15,000 円未満 \\
\hline & (4) 2,000 円以上 3,000 円未満 & (9) 15,000 円以上 20,000 円未満 \\
\hline & (5) 3,000 円以上 4,000 円未満 & (10) 20,000 円以上 \\
\hline
\end{tabular}

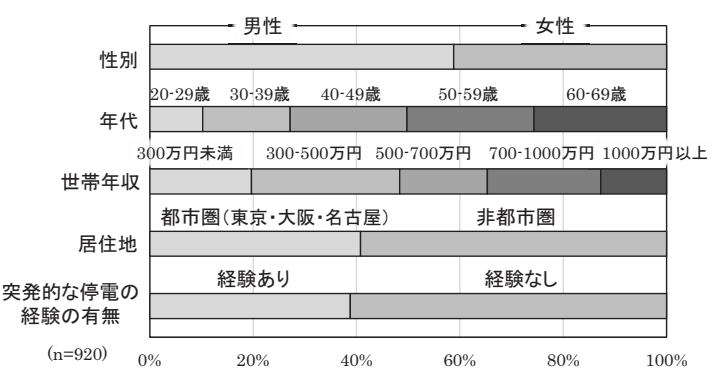

図 5 回答者の個人属性

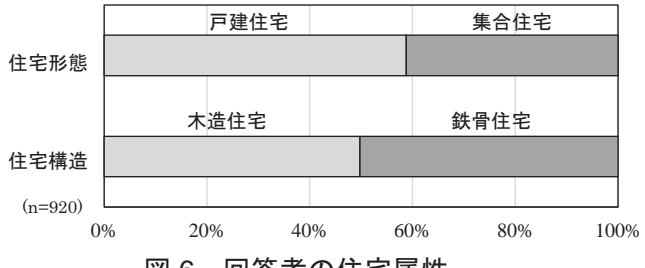

図 6 回答者の住宅属性

回答者の住宅形態が損失額原単位に及ぼす影響を把握するため, 戸 建住宅と集合住宅に分けて損失額原単位の平均值を途絶時間別に比 較した。図 7 に結果を示す。集合住宅は比較的回答にばらつきが見 られたが，どの途絶時間も集合住宅の方が戸建住宅より有意に損失 額原単位が大きい結果となった。集合住宅の方がライフライン途絶 の影響が大きいことが分かった。

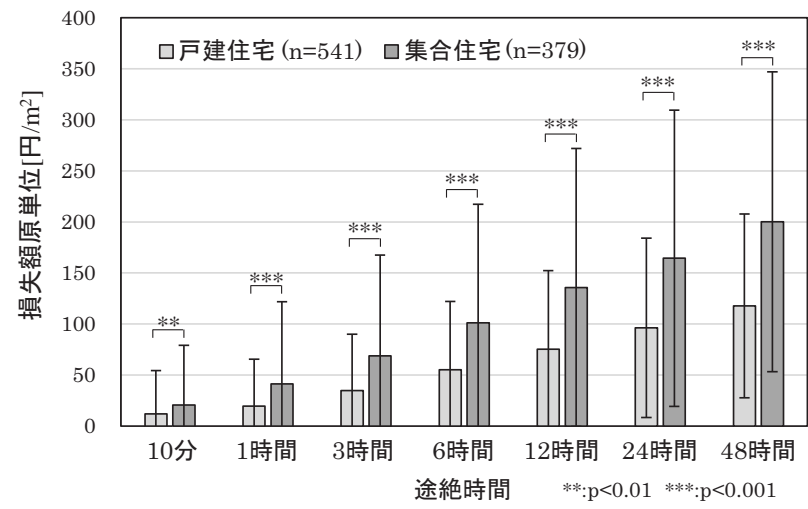

図 7 住宅形態別の損失額原単位（電力のみ途絶の場合）

回答者の居住地が停電に対する損失額原単位に及ぼす影響を把握 するため, 大都市圈（東京，大阪，名古屋） と非大都市圈に分けて 損失額原単位の平均值を途絶時間別に比較した。図 8 に結果を示す。 どの途絶時間も大都市圈のほうが非大都市圈より有意に損失額原単 位が大きい結果となった。都心部に住む居住者ほど, 停電に対する 損失を高く回答することが分かった。

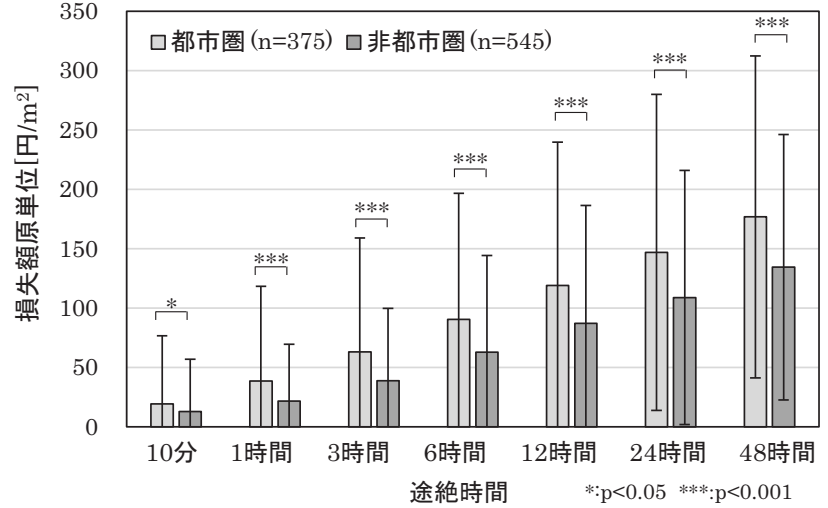

図 8 居住地別の損失額原単位（電力のみ途絶の場合）

\section{3-2 途絶回避によるレジリエンス向上効果の評価方法}

途絶時間を考慮して損失額原単位を推計するために，縦軸を損失 額原単位，横軸を常用対数軸で示した途絶時間として，損失額原単 位の推計モデルを構築した。表 9 のように, 図 7 と図 8 の結果を踏 まえて, 住宅形態と居住地を考慮した 4 つの推計モデルを導出した。 一例として, 図 9 に都市圈における戸建住宅と集合住宅の推計モデ ルをグラフ化して示す。突発的な停電が 2 日間 (2880 分) 継続した 場合, 戸建住宅では 117 円 $/ \mathrm{m}^{2}$, 集合住宅では 211 円 $/ \mathrm{m}^{2}$ の損失額原 単位といった推計結果となる。このモデルにより，電力の途絶時間 によって変化する損失額原単位を推計可能となった。

表 9 損失額原単位の推計モデル

\begin{tabular}{|c|c|c|c|c|c|}
\hline モデル & 住宅形態 & 居住地 & 定数 & 切片 & 度数 \\
\hline (1) & 戸建住宅 & 都市圈 & 21.6 & -54.6 & 202 \\
\hline (2) & 戸建住宅 & 非都市圈 & 18.1 & -47.6 & 339 \\
\hline (3) & 集合住宅 & 都市圏 & 36.8 & -82.0 & 173 \\
\hline (4) & 集合住宅 & 非都市圈 & 29.2 & -76.3 & 206 \\
\hline
\end{tabular}

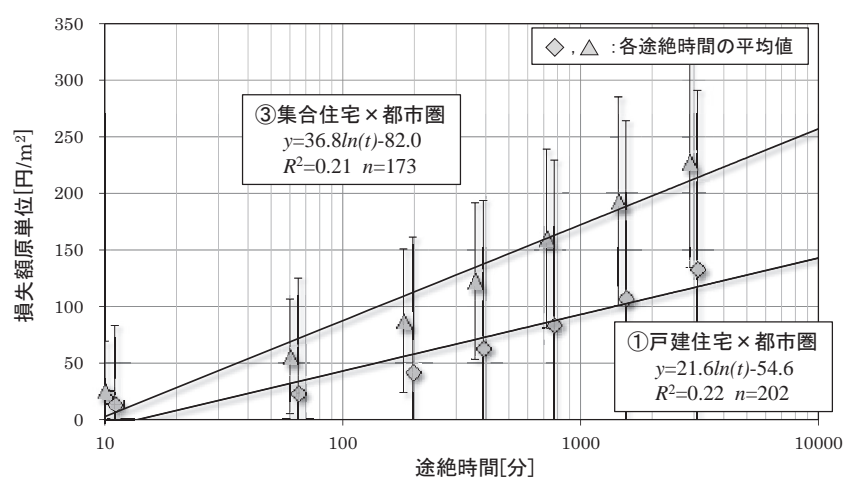

図 9 損失額原単位の推計モデル（都市圏）

住宅部門のレジリエンス向上効果は，評価対象となる住宅の延床 面積を損失額原単位に掛けあわせて算出した損失額に電力の供給力 を乗ずることで推計する。式(17)に示す推計式から住宅部門のレジ リエンス向上効果を貨幣価值で評価する。

住宅部門のレジリエンス向上効果[円/年]
$=$ 損失額原単位 $\left[\mathrm{m} / \mathrm{m}^{2}\right] \times$ 電力の供給力 $[\%] \times$ 延床面積 $\left[\mathrm{m}^{2}\right] \times$ 炎害発生確率 $[-1$ 年 $](17)$




\section{4. ケーススタディ}

本研究では, 2,3 節で述べたライフラインの途絶に備えた対策に よるレジリエンス向上効果の評価方法を用いて, 地域の特徴が異な る以下の 2 つの地区を対象としたケーススタディを行う。

（1）都心部で国際競争力の強化が求められる都市再生構想地区

（2）都市郊外の既存の住宅団地で再生が見込まれる地区

ライフラインの途絶に備えた対策として地域レベルのエネルギー システムの導入を想定する。これは, 災害時でも都市ガスの供給が 可能な中圧ガス導管からのガス供給を利用して, 電力や熱を生産す ることから, 評価方法で述べた都市ガスの供給を熱供給と同等とみ なして評価する。本研究では, 既往研究 15)で各ライフラインの供給 力が推定された地区を評価対象としたため, 供給力は既往研究 15)の 推計值を利用する。

\section{4-1 ライフラインの復旧日数と災害発生確率の設定}

地域レベルのエネルギー事業は都市再生が求められる地区で導入 が推進されていることから, 想定する災害は東京湾北部を震源とし て発生すると推測される首都直下型地震とする。内閣府のライフラ

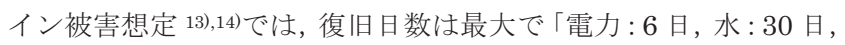
都市ガス : 42 日」と想定されている。本評価では, 早期に復旧する 建物と復旧に日数を要する建物が存在する複合事象の簡単化のため

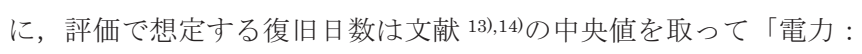
3 日, 水: 15 日, 都市ガス: 21 日」と設定した。住宅部門は, ケー ススタディにおいて都市圈の集合住宅を対象とするため, 表 9 から モデル(3)を用いる。途絶時間は業務部門と同様に 3 日とする。 ま た, 災害発生確率は文部科学省の想定 ${ }^{15}$ )から「30 年間で $70 \% 」 と$ する。

\section{4-2 都市再生構想地区を対象としたケーススタディ}

\section{(1) 対象地区の概要}

対象地区は, 都市再生緊急整備地域に指定され, 都市再生の拠点 となっている東京都港区田町駅周辺地区 ${ }^{16)}$ を対象とする。鉄道や周 辺に既成市街地と再開発エリアが混在している地区であり, 当該地 区の地域整備方針 17)では, 「都市開発事業において, 自立分散型か つ効率的なエネルギーシステムの導入を誘導」や「田町駅前及び駅 周辺の防災機能の確保を誘導」等といった方針が掲げられている。 図 10 に対象地区に導入する街区計画 9)を示す。B D 地区でそれぞ れの再開発事業に合わせた地域コージェネレーションシステム等を 含む施設を整備する対策を想定する。

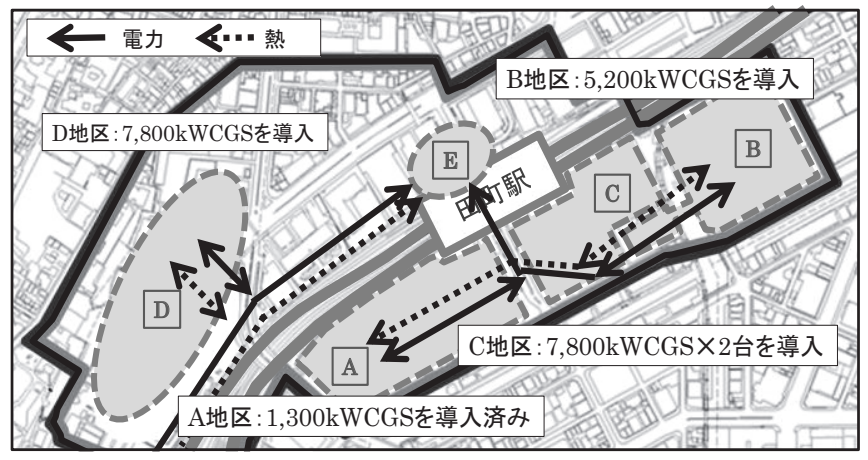

図 10 対象地区の概要（田町駅周辺地区）
(2) 対象地区の供給力の想定

既往研究 9)において, 田町駅周辺地区に地域エネルギーネットワ ークを導入した場合, 各ライフラインの供給力は電力 : $144 \%$, 熱 : $69.4 \%$ と推定されていることから $R F^{\prime}{ }$ (対策後) を算出するにあた り供給力を「電力 : $100 \%$, 水 : $50 \%$, 都市ガス : $69.4 \% 」$ と設定し た。なお，現時点では対策による水の供給力について評価ができて いないため，暫定的に水の供給力は $50 \%$ とする。

(3)レジリエンス向上効果の評価

(2)で想定した供給力を用いて, 業種別に対策前後の業務活動の回 復曲線を導出して，業種別に業務活動の向上分の面積を算出した。

一例として, 店舗（卸売・小売業）の回復曲線を図 11 に示す。

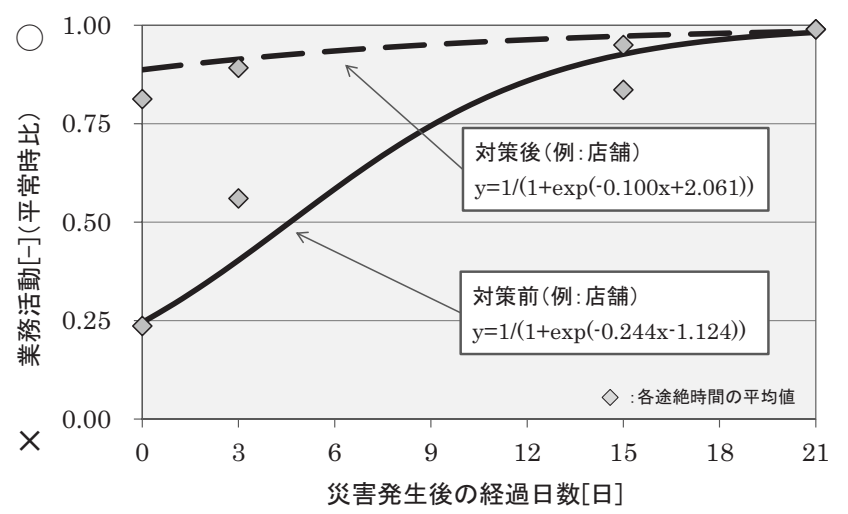

図 11 対策前と対策後の回復曲線の例（店舗（卸売・小売業））

表 10 に田町駅周辺地区における首都直下型地震を想定したレジ リエンス向上効果の推計結果を示す。結果として, 地区全体ではレ ジリエンス向上効果の合計值が年間約 1.4 億円となり, ライフライ ンの途絶に備えた対策のレジリエンス向上効果を貨幣価值で評価す ることができた。

表 10 レジリエンス向上効果の推計結果（田町駅周辺地区）

\begin{tabular}{|c|c|c|c|c|}
\hline $\begin{array}{l}\text { 建物 } \\
\text { 用途 }\end{array}$ & $\begin{array}{c}\text { 延床面積 } \\
{\left[\mathrm{m}^{2}\right]}\end{array}$ & $\begin{array}{l}\text { 原単位 } \\
\text { 業務 }\left[円 / \mathrm{m}^{2} \cdot \text { 日] }\right. \\
\text { 住宅 }\left[\text { [円 } / \mathrm{m}^{2}\right] \\
\end{array}$ & $\begin{array}{c}\text { 向上分の面積 } \\
\text { [日] }\end{array}$ & $\begin{array}{l}\text { 向上効果 } \\
\text { [百万円] }\end{array}$ \\
\hline 事務所 & 421,250 & 1,677 & 5.46 & 90.0 \\
\hline 住宅 & 89,000 & 226 & - & 0.73 \\
\hline 店舗 & 99,500 & 3,297 & 4.97 & 38.0 \\
\hline ホテル & 84,500 & 528 & 7.92 & 8.24 \\
\hline 病院 & 20,000 & 915 & 4.74 & 2.02 \\
\hline & & \multicolumn{2}{|c|}{ レジリエンス向上効果の合計值 } & 139 \\
\hline
\end{tabular}

4-3 住宅団地再生地区を対象としたケーススタディ

(1) 対象地区の概要

次に住宅団地が多くを占める地区で評価を行う。対象地区は, 少 子高齢化対応に向けて既存団地の再生事業が予定されている神奈川 県浜見平団地地区を対象と寸る。浜見平地区まちづくり計画 18)では, 老朽化した団地の建て替えと共に市南西部の生活・防災拠点として の整備が目標とされている。図 12 に対象地区に導入する街区計画 9)を示す。鉄道駅周辺との連携や下水処理場等の排熱利用を想定し た対策とする。 


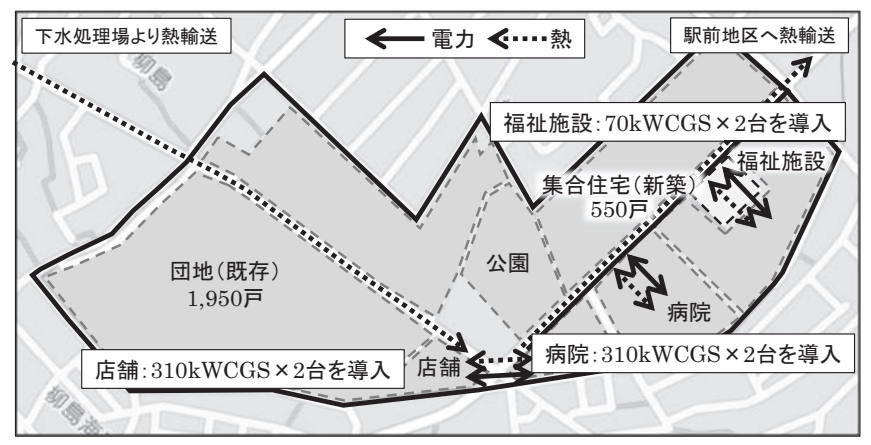

図 12 対象地区の概要（浜見平団地地区）

(2) 対象地区の供給力の想定

既往研究 9)において, 浜見平団地地区に地域エネルギーネットワ ークを導入した場合, 各ライフラインの供給力は電力 : $62.5 \%$, 熱 : $33.6 \%$ と推定されていることから, $R F^{\prime}{ }_{i}$ (対策後) を算出するにあた り供給力を「電力 : $62.5 \%$, 水 : $50 \%$, 都市ガス : $33.6 \%$ と設定し た。なお，4-2 と同様に現時点では対策による水の供給力について 評価ができていないため, 暫定的に水の供給力は $50 \%$ とする。

(3)レジリエンス向上効果の評価

浜見平団地地区においても, 業種別に対策前後の業務活動の回復 曲線を導出した。一例として, 病院の回復曲線を図 13 に示す。

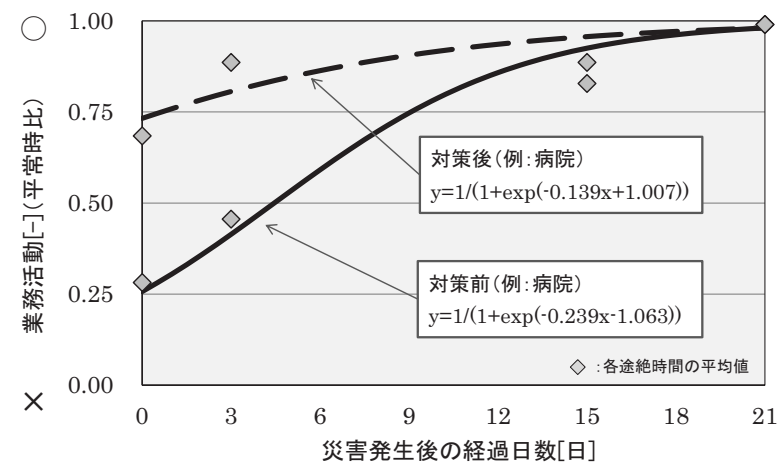

図 13 対策前と対策後の回復曲線の例（病院）

表 11 に浜見平団地地区における首都直下型地震を想定したレジ リエンス向上効果の推計結果を示す。結果として, 地区全体で年間 約 5 百万円のレジリエンス向上効果が推計され, 住宅団地再生地区 においても災害に対するレジリエンス向上効果を示すことができた。

表 11 レジリェンス向上効果の推計結果（浜見平団地地区）

\begin{tabular}{|c|c|c|c|c|}
\hline $\begin{array}{l}\text { 建物 } \\
\text { 用途 }\end{array}$ & $\begin{array}{c}\text { 延床面積 } \\
{\left[\mathrm{m}^{2}\right]}\end{array}$ & $\begin{array}{c}\text { 原単位 } \\
\text { 業務 }\left[\mathrm{H} / \mathrm{m}^{2} \cdot \text { 日] }\right. \\
\text { 住宅 }\left[\mathrm{H} / \mathrm{m}^{2}\right]\end{array}$ & $\begin{array}{c}\text { 向上分の面積 } \\
\text { [日] }\end{array}$ & $\begin{array}{l}\text { 向上効果 } \\
\text { [百万円] }\end{array}$ \\
\hline 住宅 & 139,184 & 226 & - & 0.46 \\
\hline 店舗 & 10,344 & 3,297 & 3.90 & 4.25 \\
\hline 病院 & 19,200 & 915 & 3.76 & 1.79 \\
\hline & & \multicolumn{2}{|c|}{ エンス向上効果の合計值 } & 5.11 \\
\hline
\end{tabular}

5. まとめ

本研究では, 地域エネルギー事業の推進に資することを目的とし て, ライフラインの途絶に備えた対策によるレジリエンス向上効果 の一連の評価手法を提案した。また，ケーススタディにおいて実街 区におけるレジリエンス向上効果を検証した。以下に結果を示す。
(1) 業務部門のレジリエンス評価方法の提案

非製造業の従事者にアンケート調査を実施し，業種別の RF を導 出した。また，対策により向上が見込まれる対策後の $\mathrm{RF}{ }^{\prime}$ の推計方 法や, 各ライフラインの途絶時間を考慮した業務活動の回復曲線の 導出方法を提案した。対策前後の回復曲線の差分に業務活動の原単 位を掛け合わせることで，レジリエンス向上効果を貨幣価值に換算 する方法を提案した。

（2）住宅部門のレジリエンス評価方法の提案

居住者にアンケート調査を実施し，途絶時間を考慮した停電に対 する損失額原単位を導出した。また，住宅形態と居住地を考慮した 損失額原単位の推計モデルを導出して, 途絶時間によって変化する 損失額から住宅のレジリエンス向上効果を貨幣価值に換算する方法 を提案した。

(3) ケーススタディによるレジリエンス向上効果の定量化

都市開発が見込まれる田町駅周辺地区と浜見平団地地区を対象と して，首都直下地震を想定した地域レベルのエネルギーネットワー ク導入によるレジリエンス向上効果のケーススタディを行った。両 地区において, 田町駅周辺地区では年間 1.4 億円, 浜見平団地地区 では年間 511 万円のレジリエンス向上効果が得られる試算結果とな った。これにより, 実街区における地域レベルのライフラインの途 絶に備えた対策に関する事業性評価を行う際に，本研究で提案した 評価方法を用いてレジリエンス向上効果を貨幣価值で評価できるこ とが示唆された。

また，本研究は以下のような課題が考えられる。 (1) RF の妥当性の検討

非製造業の従事者へのアンケート調查から $\mathrm{RF}$ を推計したが, $\mathrm{RF}$ 自体の妥当性の検証は不十分である。 BCP (業務継続計画) の策定 に関わる者を対象に同様の調查を行い, RF の妥当性を検討寸る必 要がある。

(2)回復曲線の妥当性の検討

本研究では, 業種別の回答の平均值から算出した RF を用いて回 復曲線を導出したが, 回答のばらつきを考慮して確率分布などで示 すことも検討する必要がある。

(3)水や都市ガスの途絶に対する住宅部門のレジリエンスの定量化

住宅のレジリエンス評価については, 電力のみの影響しか考慮で きていない。業務部門とは異なり水や都市ガスの途絶の影響も大き いことが考えられるため, 追加調査を実施して水と都市ガスの影響 も定量化する必要がある。

\section{謝辞}

本研究は一般社団法人日本サステナブル建築協会を事務局として 設置された「エネルギーコベネフィットクリエイティブタウン調査 委員会」(村上周三委員長) の活動の一部であり, 関係各位のご協力 に感謝の意を表する。 
参考文献

1）国土交通省都市局：災害時業務継続地区整備緊急促進事業, 2015

2）内閣府国土強勒化推進本部：国土強勒化基本計画, 2014.6

3) Bement Dawn, A. Skumatz Lisa New Non-Energy Benefits

(NEBs)results in the commercial/ industrial sectors ECEEE 2007

Summer Study proceedings pp.1551-1559 2007.6

4）工月良太, 伊香賀俊治, 村上周三 他 3 名: エネルギーの面的利用がもたら 寸間接的便益（NEB）に関する研究 その 2 -広域的なエネルギーの面的 利用における低炭素化対策の限界削減費用の評価, 日本建築学会環境系論 文集，第 656 号, pp.915-921, 2010.10

5）水石仁，伊香賀俊治，村上周三，他 2 名：間接的エネルギー便益（NEB） を考慮したステークホルダー別の費用便益分析と NEB の再配分に関する 考察一分散型エネルギーシステムによる都市・地域の低炭素化に関する研 究，日本建築学会環境系論文集，第 684 号, pp.175-181, 2013.2

6) 電力中央研究所 : 需要家から見た供給信頼度の重要性と停電影響, 2007.3

7) American Council for Technology: Seismic vulnerability and impact of disruption of lifelines in the conterminous United States, ACT-25, Redwood City, California, 1991

8）梶谷義雄, 多々納裕一, 山野紀彦, 他 1 名: 非製造業を対象としたライフ ライン途絶抵抗係数の推計, 自然災害科学, J.JSNDS 24-3, pp.247-255, 2005

9）日本サステナブル建築協会:エネルギーイノベーティブタウン調査報告書, 2014.6

10）内閣府防災担当：事業継続ガイドラインーあらゆる危機的事象を乗り越 えるための戦略と対応, 2013.8, http://www.bousai.go.jp/kyoiku/kigyou/ pdf/guideline03.pdf（アクセス日 2016.8.15)

11）経済産業省資源エネルギー庁：エネルギー消費統計調査（平成 26 年度）
12）国土交通省：建築物着工統計（平成 17 年度 平成 26 年度）

13）内閣府：首都直下地震による被害の概要, 2008.3, http://www.bousai. go.jp/kaigirep/kentokai/syutohukkou/pdf/sankoshiryo_2.pdf (アクセス日 2016.8.15)

14）内閣府首都直下地震対策検討ワーキンググループ：首都直下地震の被害 想定と対策について（最終報告）, 2013.12, http://www.bousai.go.jp/jishin/ syuto/taisaku_wg/pdf/syuto_wg_siryo01.pdf（アクセス日 2016.8.15）

15）文部科学省地震調查研究推進本部：過去に公表した活断層及び海溝型地 震の長期評価結果一覧, 2015

16）内閣府都市再生本部，都市再生特別措置法に基づく特定都市再生緊急整 備地域の地域整備方針, 2012.1

17）東京都都市整備局，東京の国際競争力の一層の強化に向けた都市再生の 推進, 2011.11

18）茅ヶ崎市：浜見平地区まちづくり計画, 2013.3

注

注 1）エネルギー供給停止時の損失回避効果[円/年]

$=$ 供給停止被害額原単位 $[$ 円 $/ \mathrm{kW}$ ・時間 $] \times$ 分散型電源容量 $[\mathrm{kW}]$ $\times$ 供給停止時間[時間/回] $\times$ 発生確率[回/年]

注 2) 自社の業務活動について, 適切な回答を得るために, 業務継続計画 (BCP) について聞いたことがない者や職位が一般職，主任・係長クラス，派遣 社員, その他と回答した者を対象外とした。

注 3）延床面積あたりの業務活動原単位 $\left[\right.$ 円 $/ \mathrm{m}^{2} \cdot$ 日]

二延床面積あたりのエネルギー使用量 $\left[\mathrm{GJ} / \mathrm{m}^{2}\right] /$ 売上高あたりの エネルギー使用量 $[\mathrm{GJ} /$ 百万円 $] \times 10^{6}[$ 円/百万円] $/ 365$ [日] 


\section{PROPOSAL OF AN EVALUATION METHOD FOR RESILIENCE IMPROVEMENTS CONSIDERING LIFELINE SUPPLY STOPPAGES}

Evaluation of monetary value for resilience improvements by introducing a community energy system

$$
\begin{gathered}
\text { Kaichi OTSUKA }{ }^{*} \text {, Toshiharu IKAGA }{ }^{* *}, \text { Shuzo MURAKAMI } I^{* *}, \\
\text { Ryota KUZUKI**** and Takahiro KAWAYOKE } \\
\text { * Grad. Student, Graduate School of Science and Technology, Keio Univ. } \\
\text { ** Prof., Faculty of Science and Technology, Keio Univ., Dr. Eng. } \\
\text { *** President, Institute for Building Environment and Energy Conservation, Dr. Eng. } \\
\text { **** Energy Strategy Planning Dept., Tokyo Gas Co., Ltd., Dr. Eng. }
\end{gathered}
$$

In urban areas where population and city functions are aggregated, there are calls for the construction of business continuity districts, in which energy supply is secured in times of disaster. A decentralized and self-reliant communitylevel energy network is expected to contribute to improving resilience and regional vitalization, as well as to reducing carbon emissions. However, the initial investment is high and the stakeholders involved are diverse, creating potential obstacles to the introduction of such an energy network because the necessary measures are of larger scale than a simple construction project. Prior studies have shown the need for accurate recognition of non-energy benefits (NEBs) in addition to energy benefits such as energy cost savings. Moreover, evaluation methods for various co-benefits have been proposed. Yet, NEBs accrued through risk reduction have not been evaluated with respect to temporal changes in business and daily life activities associated with lifeline utilities such as electricity, water, and gas.

In this study, we conducted a questionnaire survey of city residents and non-manufacturing workers. Using the data from the questionnaire, we developed an evaluation method for improvements in resilience. In addition, we verified the effect of improving resilience through a case study of a real urban district and a housing complex district.

The results of this research are summarized below.

(1) Proposal of an evaluation method for resilience in the business sector

In the questionnaire survey, we asked non-manufacturing workers about the effect on business activities of lifeline stoppages (electricity, water, and gas) and derived a "Resiliency Factor" according to the type of business. Then, we proposed a method for resilience improvements based on Resiliency Factor and a recovery curve for business activity according to the lifeline stoppage time, and we plotted a recovery curve for business activity according to the lifeline stoppage time. In addition, we expressed the resilience improvement in the business sector in monetary terms.

(2) Proposal of an evaluation method for resilience in the housing sector

In the questionnaire survey, we asked residents about the losses incurred as a result of electric power failure. Then, we derived a basic unit of loss due to electric power failure according to stoppage time. This basic unit was then used in an estimation model considering housing type and location to assess resilience improvements in the housing sector in monetary terms.

(3) Case study

We performed a case study of the effect on resilience of introducing a community energy network under the assumption of a large-scale earthquake. In the evaluation, the Tamachi Station district was taken as an example of urban areas and the Hamamidaira housing complex district was taken as an example of areas around existing housing complexes We found that by introduction of the community energy system, the Tamachi Station district would accrue NEBs of 140 million yen per year and the Hamamidaira housing complex district would accrue NEBs of 5.11 million yen per year. 